\title{
Clinical approaches for genital and extragenital metastasis of transmissible venereal tumor in a bitch with ovarian remnant syndrome
}

\author{
Zeynep Günay UÇMAK ${ }^{1, a, ®}$, İsmail KIRŞAN ${ }^{1, b}$, Melih UÇMAK ${ }^{1, \mathrm{c}}$, Özge ERDOĞAN BAMAÇ ${ }^{2, d}$, \\ Aydın GÜREL ${ }^{2, e}$
}
${ }^{1}$ University of İstanbul-Cerrahpaşa, Faculty of Veterinary Medicine, Department of Obstetrics and Gynecology; ${ }^{2}$ University of İstanbul-Cerrahpaşa, Faculty of Veterinary Medicine, Department of Pathology, İstanbul, Turkey. aORCID: 0000-0003-2530-1291; ' ${ }^{\mathrm{a} O R C I D: ~ 0000-0003-0780-0118 ; ~ ' ~} \mathrm{ORCID}$ : 0000-0002-8688-127X;

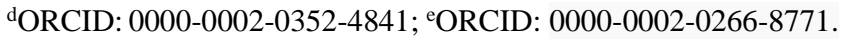

\begin{abstract}
A $25 \mathrm{~kg}, 4$ years old, Boxer breed bitch which had ovariohysterectomy section 2 years ago, was presented with weakness, loss of appetite, masses on abdominal and inguinal mammary glands and vaginal bleeding. Transmissible venereal tumor (TVT) was diagnosed with vaginal cytology. Intra-abdominal mass around the iliac artery and remnant ovary behind the right kidney were determined on ultrasonographic examination. The remnant ovary and the masses on mammary glands were removed by surgical approach. However, intra-abdominal mass could not be extirpated because of its localization during the same laparotomy. A biopsy was taken from the vaginal mass. According to histopathology, TVT and collagenous hamartoma were detected on mammary glands. Also, TVT was observed in vaginal and intra-abdominal masses. Chemotherapy protocol was arranged for intra-abdominal mass and vaginal TVT which occupied for ten weeks. Hemogram, vaginal smear and transabdominal ultrasonography were repeated before each chemotherapy course. Size of the intra-abdominal mass, pulsatility index (PI) and relative index (RI) values of iliac artery were evaluated with B-mode ultrasonography and doppler ultrasonography during the treatment, respectively. As a result, positive correlation between PI and RI values were determined. In the presented case, TVT and its metastases were successfully treated with both surgery and chemotherapy. It was concluded that evaluation of the metastases with doppler ultrasonography will be favorable to reveal the hemodynamic alterations of related organs or tissues.
\end{abstract}

Keywords: Canine, metastasis, transmissible venereal tumor.

\section{Ovaryan remnant sendromlu bir köpekte bulaşıcı veneral tümörün genital ve ekstragenital metastazlarına klinik yaklaşımlar}

Özet: Dört yaşında, 25 kg ağırlığında, 2 yıl önce ovariohisterektomi operasyonu uygulanmış, Boxer ırkı dişi bir köpek; halsizlik, iştahsızlık, vajinal kanama, abdominal ve inguinal meme bezlerinde kitle şikayetiyle getirildi. Vajinal sitolojik muayene ile bulaşıcı veneral tümör (TVT) teşhis edildi. Ultrasonografik muayenede, arteria iliaka etrafinda yer alan intra-abdominal bir kitle ve sağ böbreğin gerisinde kalıntı ovaryum varlığı tespit edildi. Kalıntı ovaryum ve meme bezlerindeki kitleler cerrahi yaklaşım ile uzaklaştırıldı. Laparotomi sırasında intra-abdominal kitle lokalizasyonu nedeniyle esktirpe edilemedi. Vajinal kitleden biyopsi örneği alındı. Histopatolojik inceleme neticesinde, meme bezlerinde TVT ve kollajenöz hamartom, vajinal ve intrabominal kitlelerde de TVT varlığı saptand. Vaginal ve intra-abdominal TVT kitleleri için 10 haftalık kemoterapi protokolü oluşturuldu. Her kemoterapi öncesi hemogram, vajinal smear ve transabdominal ultrasonografi tekrarland. Tedavi süresince intra-abdominal kitlenin boyutu ve arteria illiaka'ya ait pulsatil indeks (PI) ve relative indeks (RI) değerleri sirasıly B-mod ultrasonografi ve doppler ultrasonografi ile değerlendirildi. Bunun sonucunda, PI ve RI değerleri arasında pozitif korelasyon tespit edildi. Sunulan bu vakada, TVT ve metastazları hem cerrahi yaklaşımla hem de kemoterapi ile başarılı bir şekilde tedavi edildi. Metastazların doppler ultrasonografi ile değerlendirilmesinin, ilgili organ veya dokuların hemodinamik değişikliklerini ortaya koymak için faydalı olacağı sonucuna varıldı.

Anahtar sözcükler: Köpek, metastaz, bulaşıcı veneral tümör. 
Canine transmissible venereal tumor (CTVT) is a contagious venereal tumor of dogs which are infected with close contact and mating without noticing any breed, age and sex $(5,11)$. However, CTVTs are commonly seen between 2 and 8 years old (6). The clinico-pathological feature of CTVT is cauliflower-like, pedunculated, lobular, papillar or multilobular. The surface of the tumor is usually ulcerated, hemorrhagic and friable (13). CTVTs are easily diagnosed with anamnesis, clinical and cytological examinations. Even if exfoliated cells of the tumors can be definitely obtained by swabs or fine needle aspiration, cytogenetic and molecular techniques are also applied for diagnosis $(7,17,18)$. Although TVT is usually a benign neoplasm, it starts to transform into an invasive and malignant form that cause metastases at the range of $5-17 \%$ (23). The occurrence of the tumor and its metastases depends on the immune system of the dog (26, 27). Metastases commonly occur in males (16\%) rather than in females (2\%) (6). Nasal mucosa, gluteal region, maxillar gingiva, subcutaneous tissue, skin, lymph node, uterus, ovarium, brain and ocular metastases of CTVTs are reported $(3,12,14,25)$. Regional lymph node metastases are frequently seen in males with large tumors (18). Several treatments can be applied for CTVT such as radiotherapy, chemotherapy, immunotherapy, biotherapy and excisional surgery (22). But the autogenous vaccine was not suitable in the treatment of the bitches with TVT (9). Chemotherapy is the most effective and common method for treatment that provides good prognosis in CTVT cases (1). However, it was reported that CTVT could be successfully treated by doxorubicin (10).

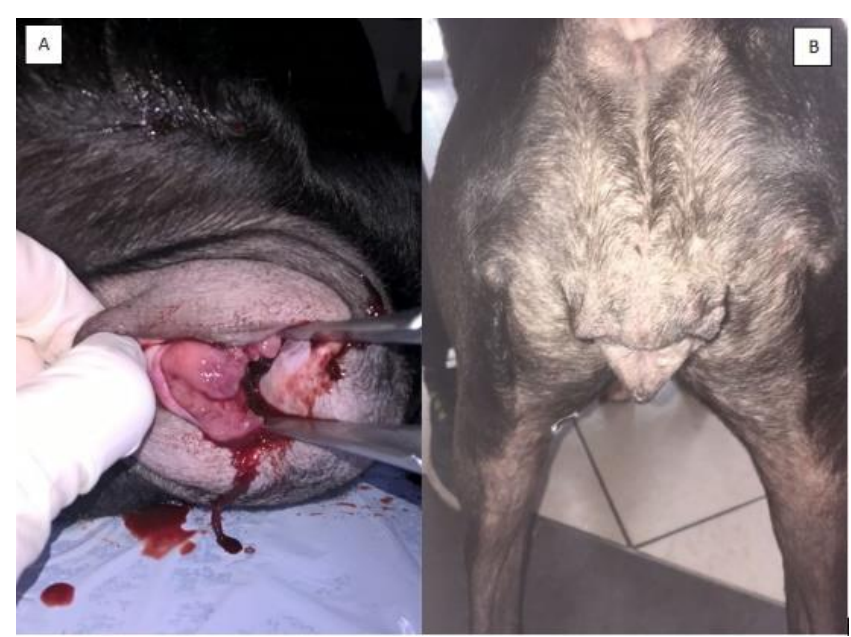

Figure 1. A. Hemorrhagic vaginal discharge and intra-vaginal mass on the presentation day.

B. Vulvar condition at the end of the chemotherapy.
A $25 \mathrm{~kg}, 4$ years old, Boxer breed bitch was presented with weakness, inappetence, masses on abdominal and inguinal mammary glands and vaginal bleeding. Although ovariohysterectomy was performed two years ago, the bitch continued to come into heat regularly. Upon clinical examination, vulvar swelling, bloody vaginal discharge, round-shape and edematous intra-vaginal mass (Figure 1) were detected in addition to masses on mammary glands. Vaginal smear revealed the existence of abundant transmissible venereal tumor cells, erythrocytes and intermediate cells (Figure 2). Ovarian remnant tissue behind the right kidney and a mass $(4.14 \mathrm{x}$ $6.24 \mathrm{~cm}$ ) around iliac artery were diagnosed by transabdominal ultrasonography. The complete blood count and biochemistry revealed normal reference ranges, only mild anemia was detected. Surgical intervention was decided to perform for removal of the remnant ovary and mammary glands. After the bitch was premedicated with atropine sulfate $(0.03 \mathrm{mg} / \mathrm{kg}, \mathrm{sc})$ (Atropin $\AA$, Teknovet, Turkey), general anesthesia was induced with propofol $1 \%$ (4 mg/kg, iv) (Lipuro $\AA$, Braun, England) and maintained with isoflurane (3\%) (Forane likid $\AA$, Abbott Laboratories, England) and oxygen (0.5-1\%). Though remnant ovary was removed after laparotomy, localization of the intra-abdominal mass prevented to extirpate it from iliac artery with surgical intervention. Total mastectomy was performed and biopsy was taken from the vaginal mass in the same anesthesia. Chemotherapy was decided to perform for treatment of intra-abdominal mass and CTVT. For the postoperative care, ranitidin $(2 \mathrm{mg} / \mathrm{kg}$, im, SID, Ulcuran ${ }^{\circledR}$, Yavuz, Turkey), enrofloxacin $(5 \mathrm{mg} / \mathrm{kg}$, sc, SID, Baytril-K® 5\%, Bayer, Turkey), cyanocobalamin (50 mcg/kg, SID, Dodex ${ }^{\circledR}$, Deva, Turkey) and Iron III Hydroxide Polimalose $(20 \mathrm{mg} / \mathrm{kg}$, im, SID, Ferrum Hausmann ${ }^{\circledR}$, Abdi İbrahim, Turkey) was applied to the bitch until leucocytosis and anemia had disappeared. Meloxicam (0.04 mg/kg, im, Melox ${ }^{\circledR}$, Nobel, Turkey) was prescribed for management of the postoperative analgesia. Mammary and vagina tissues were previously fixed in $10 \%$ buffered formalin, embedded in paraffin and sectioned at $4 \mu \mathrm{m}$ to examined by light microscopy. The dimensions of the tumoral mass that was extirpated from the inguinal mammary lobe and the vagina were $10 \mathrm{~cm} \mathrm{x}$ $6 \mathrm{~cm} \mathrm{x} 5 \mathrm{~cm}$ and $2 \mathrm{~cm} \times 2 \mathrm{~cm} \times 1 \mathrm{~cm}$, respectively. The histological examination revealed round to polyhedral cells arranged in densely packed masses separated by fine strands of connective tissue both in the inguinal mammary lobe and vagina that were exhibited the existence of TVT (Figure 3A,3B,3C). Hamartoma was observed in all the other mammary lobes (Figure 3D).

Due to hematologic examination revealed anemia (erythrocytes: $2.82 \mathrm{M} / \mu \mathrm{L}$, haematocrit: $18.2 \%$, haemoglobin: 5.3 g/dL, MCH: 18.8 pg, MCHC: $29.1 \mathrm{~g} / \mathrm{dL}$ ), blood 
transfusion was applied one week before the first chemotherapy cycle. After hemagramme parameters were suitable for chemotherapy treatment, vincristine sulfate $\left(0.025 \mathrm{mg} / \mathrm{kg}\right.$, Vincristine ${ }^{\circledR}$, Kocak Farma, Turkey) was administered with $0.9 \% \mathrm{NaCl}$ isotonic serum $(10 \mathrm{ml} / \mathrm{kg}$, Deva ${ }^{\circledR}$, Turkey) intravenously to the bitch once a week for ten weeks. Chemotherapy section had been paused for a week at the end of the sixth cure but immediately after TVT cells were cytologically detected, the cure had continued four more weeks. Hemogram and vaginal cytology were repeated before each course of chemotherapy. Cyanocobalamin (Dodex ${ }^{\circledR}$, Deva, Turkey) was prescribed to avoid the anemia during the cure. However, doppler ultrasonography was performed to evaluate the mass around iliac artery in every week before chemotherapy treatment (Figure 4). The mass exhibited a decrease in size during chemotherapy protocol was applied and its size stayed at $1.97 \times 3.84 \mathrm{~cm}$ which is anatomically compatible with median iliac lymph node (Figure 4). At the end of the chemotherapy, hemogram parameters were measured in the reference ranges.

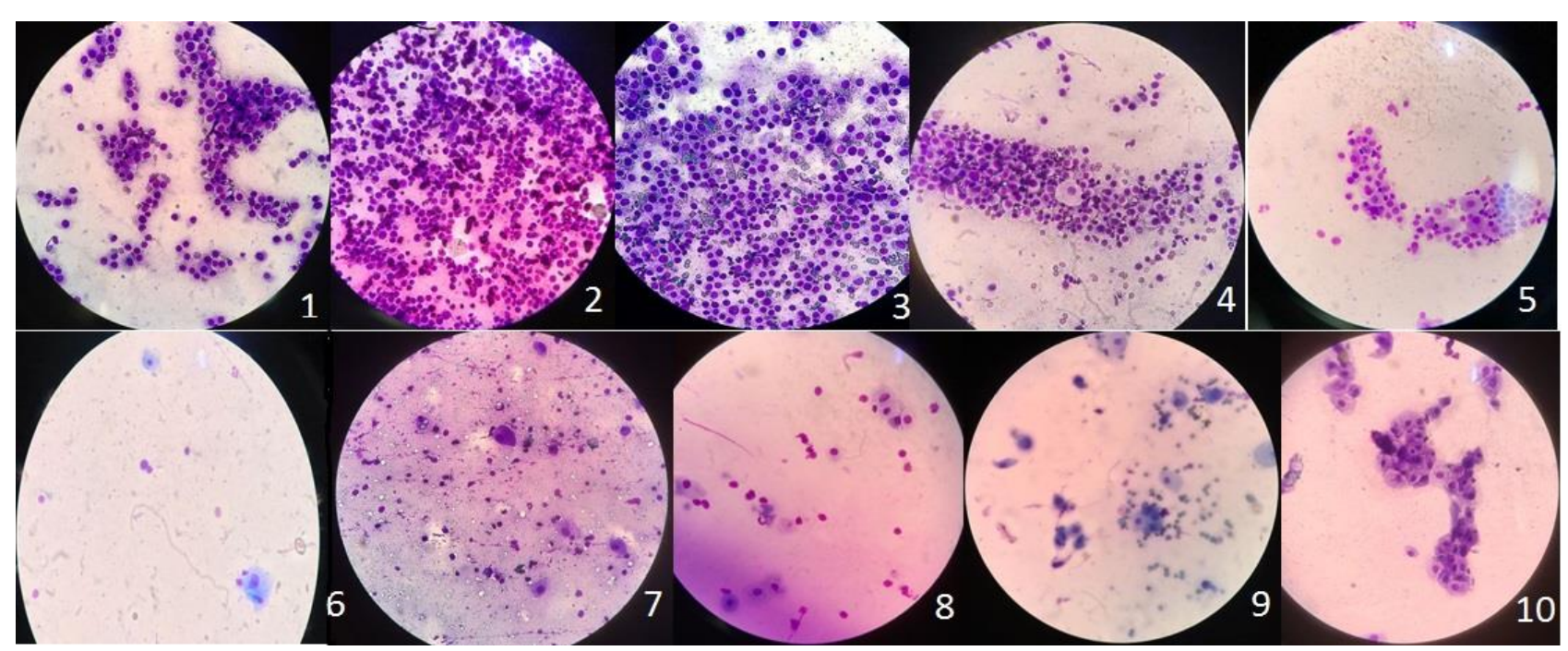

Figure 2. Vaginal cytology images during chemotherapy $\left(1^{\text {st }}-10^{\text {th }}\right.$ week).

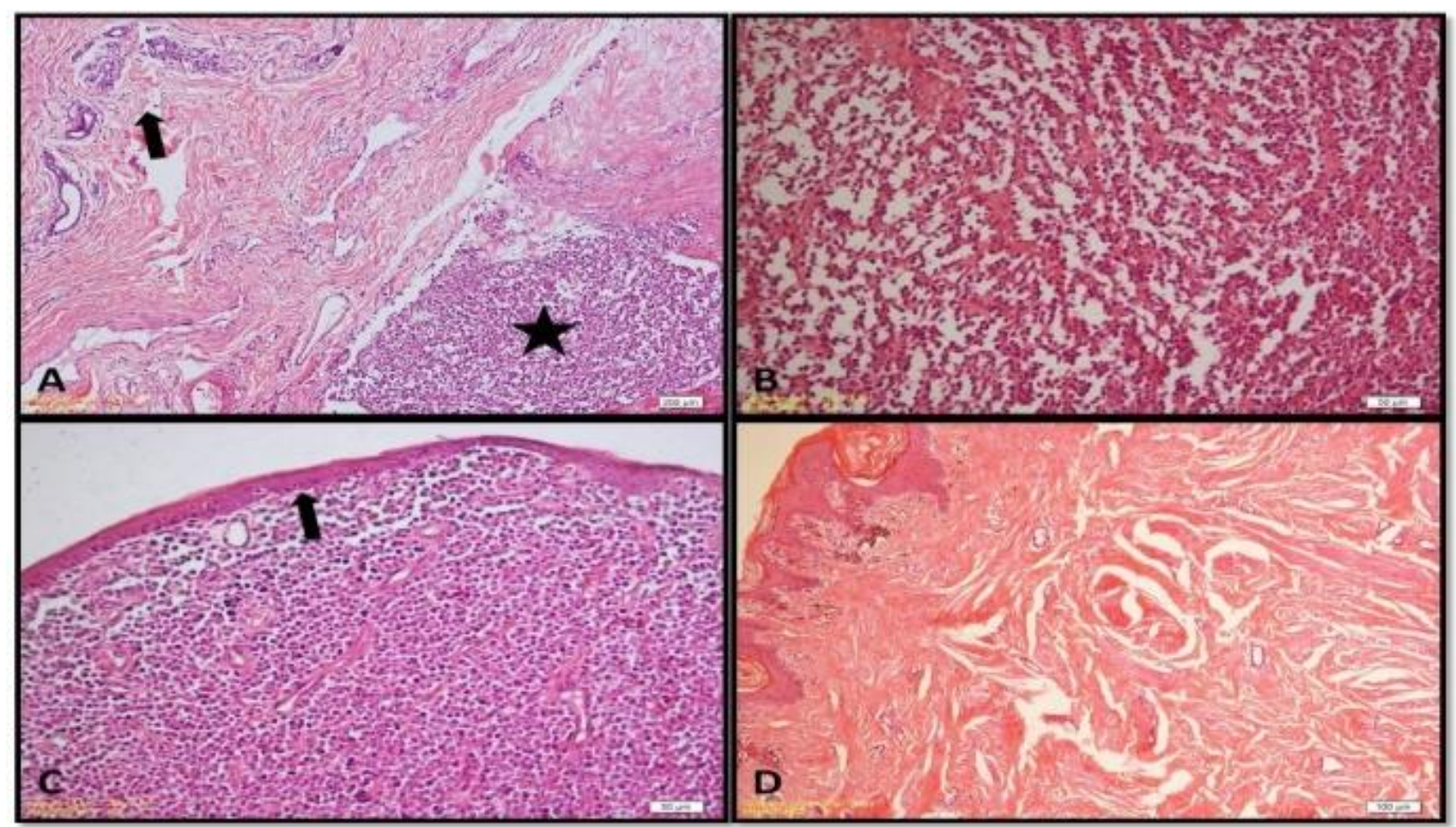

Figure 3. A. Inguinal mammary lobe. Mammary glands (arrow). Area of transmissible venereal tumor (star). B. Closer appearance of the transmissible venereal tumor. The tumor cells are arranged in densely packed masses separated by fine strands of connective tissue. C. Vagina. Transmissible venereal tumor. Round to polyhedral cells are arranged in sheets beneath the mucosa (arrow). D. Mammary tissue. Hamartoma. 

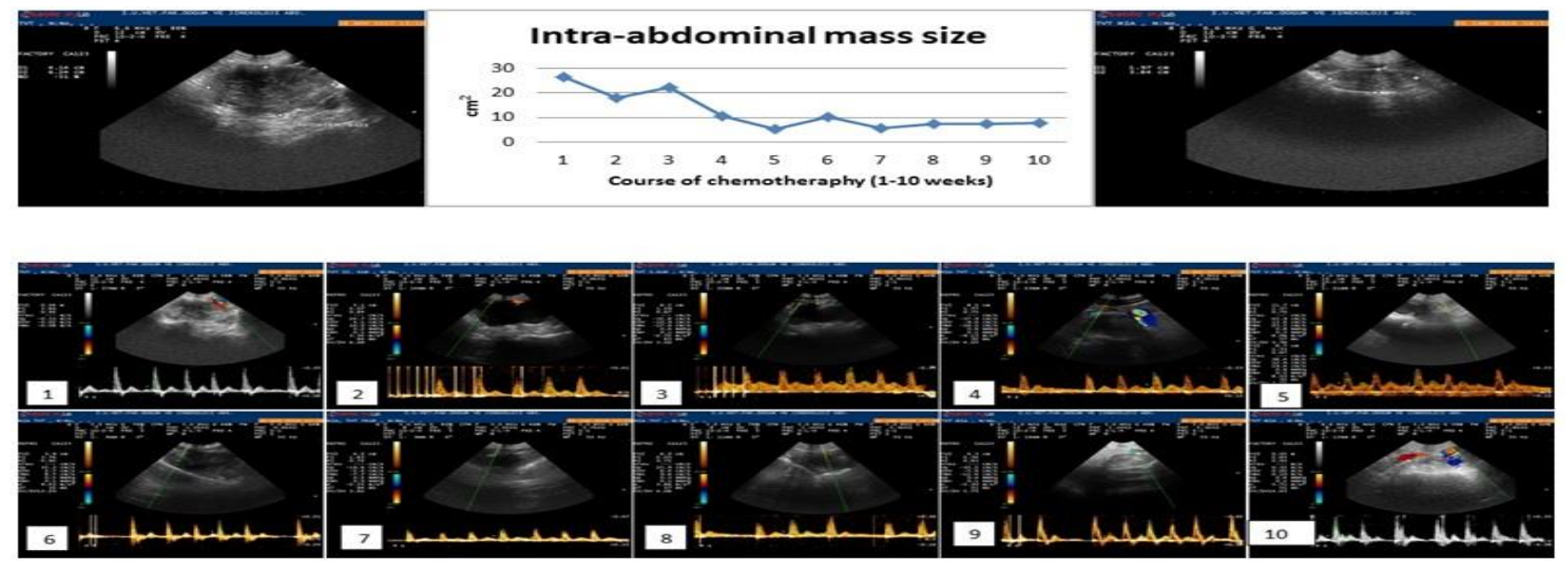

Figure 4. Size of the mass around median iliac lymph node by B-mode USG: Before and after the chemotherapy, respectively. Doppler USG findings during chemotherapy for ten weeks.

The ovariohysterectomized bitch exhibited estrus signs because of ORS and TVT contaminated during mating in the presented case, in line with Turna Yilmaz et al (24) reported that CTVT can occur in bitches with ORS. Also, the shape of the intravaginal TVT mass was round and lobular in this case unlike with Champour et al. (8) reported as cauliflower-like feature in their report. In contrast with Kevin et al. (16) reported that CTVTs were rarely metastasized, genital and extragenital metastasis of CTVT was evaluated in the presented case. The occurrence of the metastases was thought to be due to the suppression of the immune system as Behera et al. (4) reported. Transabdominal B-mode ultrasonography and doppler ultrasonography were preferred to evaluate the metastatic mass around the iliac artery, contrarily with the researchers' $(21,25)$ imaging techniques (radiography and computed tomography). Pulsatility index is the most sensitive index for differentiating abnormal waveforms which are used in obstetric and abdominal evaluations (20). In line with the researchers' report (20), PI and RI values are measured to evaluate the hemodynamics of the metastasis in a gynecologic pathology that was correlated statistically significant $(\mathrm{P}<0.001)$ according to Spearmann correlation test. This results indicate that metastatic mass on the iliac lymph node affects the blood flow in iliac artery negatively. It was concluded that doppler ultrasonography should be performed to evaluate the blood flow where the metastasis occurs in TVT cases and it will be a useful tool for examination of blood circulation in the affected tissues.

Two different treatment techniques were applied for the management of TVT in the presented case. In line with Nak et al. (19), metastasis of TVT on inguinal mammary glands was treated by surgery. But chemotherapy protocol was performed for intravaginal mass and its metastasis on median iliac lymph node due to the inoperable location.
Vincristine sulfate administrated intravenously in the same dose that Jacob et al. (15) reported. As Kevin et al. (16) notified that TVT and its metastasis were very invasive in the presented case. Because of that reason, the chemotherapy treatment for them took ten weeks.

Hamartoma is a lesion between developmental disorder and benign tumor of various body parts and organs which occurs frequently in human but rare in domestic animals (2). Although the researchers (2) stated that hamartoma occurs rarely in domestic animals, it had seen together with TVT in mammary glands in the presented report. Also, they were successfully treated by surgical intervention without recurrence in postoperative two years.

It was concluded that TVT can complicate with different pathologies such as hamartoma in genital organs, and it can take form in extra-genital tissues. Evaluation of intra-abdominal metastasis of TVT with doppler ultrasonography will be favorable to reveal the hemodynamic alterations of related organs or tissues. Both surgery and chemotherapy are performed as suitable treatment options for CTVT. For the prophylactic purpose, ovariohysterectomy or ovariectomy should be performed to avoid the spread of TVT.

\section{Conflict of Interest}

The authors declared that there is no conflict of interest.

\section{References}

1. Amber EI, Henderson RA, Adeyanju JB, et al (1990): Single-drug chemotherapy of canine transmissible venereal tumour with cyclophosphamide, methotrexate or vincristine. J Vet Intern Med, 4, 144-147.

2. Bartyzel BJ, Max A, Gruszczynska J, et al (2017): Hamartoma: a rare developmental disorder. Med Weter, 73(4), 202-207. 
3. Baştan A, Baki Acar D, Cengiz M (2008): Uterine and ovarian metastasis of transmissible venereal tumor in bitch. Turk J Vet Anim Sci, 32(1), 65-66.

4. Behera SK, Kurade NP, Monsang SW, et al (2012): Clinico-pathological findings in a case of canine cutaneous metastatic transmissible venereal tumor. Vet Arhiv, 82(4), 401-410.

5. Betamuzi EK (1992): Risk factors associated with canine TVT in Tanzania. Prevent Vet Med, 13, 13-17.

6. Boscos CM, Ververidis HN (2004): TVT-Clinical findings, diagnosis and treatment. Proceedings of the $29^{\text {th }}$ World Congress of the World Small Animal Veterinary Association.

7. Castro KF, Strakova A, Tinucci-Costa M, et al (2017): Evaluation of a genetic assay for canine transmissible venereal tumour diagnosis in Brazil. Vet Comp Oncol, 15(2), 615-618.

8. Champour M, Ojrati N, Nikrou A, et al (2014): First report of diffuse cutaneous canine transmissible venereal tumor in Iran. Comp Clin Pathol, DOI 10.1007/s00580014-1973-Z

9. Çizmeci SÜ, Köse AM, Aydın İ, et al (2012): Transmissible venereal tümörlü dişi köpeklerde otojen aşı uygulamast. Eurasian J Vet Sci, 28(4), 220-223.

10. Çizmeci SÜ, Köse AM, Aydın İ, et al (2012): Clinical efficiency of Doxorubicin and Cisplatin in treatment of transmissible venereal tumor of bitches. Revue Méd Vét, 163(11), 516-521.

11. Das U, Das AK (2000): Review of canine transmissible venereal sarcoma. Vet Res Commun, 24, 545-556.

12. Ferreira AJA, Jaggy A, Varejao AP, et al (2000): Brain and ocular metastases from a transmissible venereal tumour in a dog. J Small Anim Pract, 41, 165-168.

13. Ganguly B, Das U, Das AK (2016): Canine transmissible venereal tumour: a review. Vet Comp Oncol, 14(1), 1-12.

14. Gurel A, Kuscu B, Gulanber G, et al (2002): Transmissible venereal tumors detected in the extragenital organs of dogs. Israel J Vet Med, 57(2), 23-26.

15. Jacob A, Bhanuprakash AG, Choudhary SS, et al (2015): Therapeutic management of transmissible venereal tumor in canine. Indian J Vet Med, 35(1), 81-85.
16. Kevin AH (2002): Veterinary oncology: the practical veterinarian. Butterworth-Heinemann, Elsevier, USA.

17. Liao KW, Lin ZY, Pao HN, et al (2003): Identification of canine transmissible venereal tumor cells using in situ polymerase chain reaction and the stable sequence of the long interspersed nuclear element. J Vet Diagn Invest, 15(5), 399-406.

18. Mello Martins MI, Ferreira de Souza F, Gobello C (2005): The canine transmissible venereal tumor: Etiology, pathology, diagnosis and treatment. IVIS, A1233.0405.

19. Nak D, Mısırlığlu D, Nak Y, et al (2004): Transmissible venereal tumor with mammary gland metastase in a bitch. Vet Bilimleri Derg, 20, 99-102.

20. Nelson TR, Pretorius DH (1988): The doppler signal: where does it come from and what does it mean? Am J Roent, 151(3), 439-447.

21. Ojeda J, Mieres M, Soto F, et al (2018): Computer tomographic imaging in 4 dogs with primary nasal canine transmissible venereal tumor and differing cellular phenotype. J Vet Int Med, DOI: 10.1111/jvim.15125.

22. Purohit G (2008): Canine transmissible venereal tumor: $A$ review. Internet J Vet Med, 6(1), 1-7.

23. Richardson RC (1981): Canine transmissible venereal tumor. Comp Contin Educ Pract Vet, 3, 951-956.

24. Turna Yılmaz O, Uçmak M, Gunay Z, et al (2013): Vaginal fold prolapse and transmissible venereal tumour related to ovarian remnant syndrome in a bitch: a case report. Vet Med, 58(12), 628-632.

25. Turna O, Karabağı M, Cetin AC, et al (2017): Metastasis of canine transmissible venereal tumor to median iliac lymph nodes and evaluation of treatment with computed tomography. Proceedings of $4^{\text {th }}$ International VETIstanbul Group Congress.

26. Uçar M (2016): Transmissible venereal tumor: a review. Kocatepe Vet J, 9(3), 230-235.

27. Yang TJ (1988): Immunobiology of a spontaneously regressive tumor, the canine transmissible venereal sarcoma. Anticancer Res, 8(1), 93-95. 